\title{
Analysis of Compliance and Audit
}

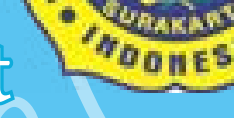
\section{Opinion Correlation and Causes of Failure} in Detecting Non-Compliance a Study or Local Government

Abdullah Lathif Elbaaqy Habiby ${ }^{1}$, Irwan Taufiq Ritonga ${ }^{2}$

${ }^{1}$ Alumni of Master in Accounting, Faculty of Economics and Business, Universitas Gadjah Mada ${ }^{2}$ Department of Accounting, Faculty of Economics and Business, Universitas Gadjah Mada

email: irwanritonga@ugm.ac.id

\section{Keywords:}

Level of Compliance, Audit Opinion, the Audit Board, Local Government, Financial Statements

\section{ABSTRACT}

This study aims to analyze the correlation between level of local government compliance with laws/regulations and audit opinions on Local Government Financial Statements (LGFS) and to identify causes of failure in detecting non-compliance, including non-compliance that contains elements of fraud, in LGFS audit. The method used is explanatory sequential mixed methods with a content analysis approach on fifty four LGFS samples and interview the auditors of the Audit Board of Republic of Indonesia (the AB). The results show that there is a correlation between level of compliance of local government and audit opinion on LGFS, but there are risk in detecting non-compliance and risk of errors in audit opinion caused by different concepts in determining fraud, unclear guidelines on compliance testing, different concept of materiality among the $\mathrm{AB}$ auditors, failure to update programs audit, potential threats/dangers experienced by auditors, and failure to reduce auditors' negative perception on working protection. The limitation of this study is that participants only involve auditors from three representative offices originating from Java and do not conduct confirmation to the unit responsible for the preparation of audit guidelines and units that deal with legal issues. This research implied that the $A B$ must increase effectiveness of audit quality assurance to improve audit quality and the $\mathrm{AB}$ auditors should be able to apply the principle of due professional care in carrying out LGFS audit so that audit quality is maintained. 
To realize successful implementation of state governance, state finance must be managed in an orderly manner, comply with laws and regulations, efficient, economical, effective, transparent and responsible [1]. Therefore, each head of local government is required to account for the management of the state finances to the House of Representatives in the form of financial statements that have been audited by the Audit Board of Indonesia (the $\mathrm{AB}$ ) no later than six months after the fiscal year ends [1]. Accordingly, the AB must conduct an audit of the management of state finances as also mandated by the Law of the Republic of Indonesia Number 15 of 2004 concerning the Audit of Management and Responsibility of State Finances. One of the most anticipated results of the $\mathrm{AB}$ audits is the audit opinion on government financial statements.

In the last three years, the $\mathrm{AB}$ has been in public spotlight. The reason is that there are several numbers of local government heads who are entangled in legal problems due to violations of the laws and regulations even though the local government financial statements (LGFS) of local government that they lead get an unqualified opinion from the $\mathrm{AB}$. Some of them have even been named as suspects of corruption. Indonesia Corruption Watch (ICW) states that ten local government heads are suspected of corruption after their LGFSs were awarded by unqualified opinion by the $\mathrm{AB}[2]$.

Then, why the opinion given by the $\mathrm{AB}$ does not reflect the level of compliance of the local government with legislation? Moermahadi Soerja Djanegara, as chairman of the $\mathrm{AB}$, stated that the unqualified opinion do not guarantee that the entity in question do not have corruption because the audit of financial statements is not specifically aimed at detecting corruption. However, the $A B$ is obliged to disclose if there is non-compliance or disobedience whether it influences the audit opinion on the financial statements or not [3]. Furthermore, the statement is not entirely correct. The State Financial Audit Standard (The SFAS) regulates that auditors must design an audit to provide adequate assurance to detect non-compliance with the provisions of the legislation and other legal products that have a direct and material effect on the main points/information on the subject matter being audited. The auditors must also identify risk factors for fraud and assess risk of non-compliance with statutory provisions caused by fraud. This risk must be considered as significant risk. If there is a risk of non-compliance with statutory provisions indicating fraud that significantly affects the subject matter/information on the subject matter audited, the auditors must modify the procedure to identify the occurrence of fraud and/or non-compliance, and determine its impact on the subject matter/ information on the subject matter checked [4].

Thus, the audit opinion given by the $\mathrm{AB}$ on the LGFS should be able to reflect level of compliance of the local government with the legislation. Therefore, authors are interested in researching the correlation between level of compliance of the local government with the legislation (here and after is called level of compliance) and the audit opinions on LGFS (here and after is called audit opinion) given by the $\mathrm{AB}$. In addition, authors also aim to answer why there is still problem of non-compliance that is not detected by auditors as indicated by the existence of a number of local government heads who are caught in a problem of corruption (fraud) even though the LGFS obtain unqualified opinion?

Authors hope that this research can contribute to auditors and users of audit report related to the process of determining audit opinion in the audit of LGFS, particularly related to the level of compliance with state financial management laws and regulations.

\section{LITERATURE REVIEW}

\section{Auditors' Role and Role Theory}

In the process of state finances auditing, there are three parties involved, namely the $A B$, those responsible, and users of audit reports [4]. The $\mathrm{AB}$ is a state institution that the duty and authority of which are to audit the management and responsibilities of state finances. The responsible party is the audited party consisting of the president, ministers, and local government heads. This party is responsible for information on the subject matter, managing the subject matter, and following up on the results 
of the audit.Users of audit reports are representative institutions, government, and other parties who have an interest in the Audit Report. Each party in an organization is filled with people whose duties and responsibilities are clearly defined, usually in written form [5].

In this study, authors focus the analysis on the $\mathrm{AB}$ as the state financial auditors. In their book, Siegel et al., (1989) and Supriyono (2015) define roles as someone's part that is played in their interactions with others. Furthermore, they also define social roles as rights, duties, obligations, and proper behavior of people who hold certain positions in particular social contexts. In official organizations, such as the $A B$, this role is defined explicitly in the form of guidelines or regulations.

The actual behavioral component of the role is called the norm. Norms are expected and needed behaviors that are appropriate for specific roles [5]. For example, auditors are expected to carry out their audit duties properly, following the standards and ethics set for them. Based on Role Theory, auditors can be seen as a status or profession in the social system [7]. Since they are in a position of a profession, auditors must comply with a resolution or decision made by public to them. Failure in carrying out the provision of social roles cannot be tolerated. Sanctions or penalties can be imposed on people who violate these provisions (Siegel et al., 1989 and Davidson, 1975 in Oseni et al., 2012).

In Indonesia, public has set a set of standards, in the form of Public Accountant Professional Standards (PAPS) containing audit standards (AS), which must be obeyed by auditors in carrying out audits. In the context of auditing state finances, the $\mathrm{AB}$ has set State Financial Audit Standards (SFAS) as a standard and guideline that must be adhered to. Based on SFAS, the AB must carry out its main duties, functions, and authorities economically, efficiently, and effectively based on statutory regulations. Furthermore, each $\mathrm{AB}$ member and state financial auditor must maintain dignity, honor, image, and credibility of the $\mathrm{AB}$ in carrying out its duties [4]. To realize this, besides being independent and having integrity, the $\mathrm{AB}$ must also be professional in carrying out audits. The SFAS defines professionalism as an ability, expertise, and professional commitment in carrying out tasks accompanied by due care, thoroughness, and carefulness, and is guided by the standards and provisions of legislation [4]. The same thing is also regulated in PAPS (SA 200); competence and professional precision are two of the basic principles in terms of code of ethics and must be obeyed by auditors. In addition, auditors must also use professional judgment in planning and carrying out audits of financial statements.

Thus, it becomes clear that in social order of society, auditor of the $\mathrm{AB}$ has a social role in a profession and must obey the norms set for them. These norms are specified in PAPS (general) and SFAS (specifically). Both of the norms regulate specifically that the auditors, in carrying out planning and implementation of audit, must act professionally, by exerting all efforts carefully (due care), thorough and careful, and based on rules and standards set. This intends to make audit and its results as outlined in the audit report have high quality, including the quality of the opinion given. The high quality of audit is certainly expected in the midst of the government's efforts and general objectives of the $A B$ in creating a clean and free government from corruption, collusion and nepotism [4]. Conversely, the failure of auditors in obeying the norm can result in low quality of the audit report which means that the AB's objectives, in general, cannot be achieved.

The SFAS regulates that auditors must design audits to provide sufficient confidence to detect non-compliance with statutory provisions and other legal products that have a direct and material effect on the subject matter/information of the subject matter audited. The auditors must also identify fraud risk factors and assess the risk of non-compliance with statutory provisions caused by fraud. These risks must be considered as significant risks. If there is a risk of non-compliance with statutory provisions indicating fraud that significantly affects the subject matter/information on the subject matter audited, the auditors must modify procedure to identify the occurrence of fraud and/or non-compliance, and determine its impact on the subject matter/information on the subject matter checked [4]. Thus, the audit opinion given by the $\mathrm{AB}$ on LGFS should be able to reflect the level of compliance of local government with the legislation. 


\section{Previous Studies}

Several researchers had conducted studies on this issue, although they do not specifically study the correlation between compliance levels and the AB's opinion. Studies conducted by Safitri (2015) and [9] show that findings of non-compliance with laws and regulations significantly influence audit opinion. The direction of the correlation is negative, which means that the more the number of findings on non-compliance with laws and regulations, the less the probability of giving an unqualified opinion by the AB to LGFS. Also Ningsih (2015) finds that accounts that are often excluded in the AB's opinion are mainly caused by a weak internal control system, non-compliance with laws and regulations, and inefficiency and ineffectiveness. Unfortunately, those studies that have been carried out ignore the concept of materiality of value findings and only focus on the frequency of occurrence. Ignorance of the concept of materiality can be fatal because materiality is very important factor in the formulation of audit opinion.

\section{Hypothesis Development}

Based on Role Theory, auditors must carry out audit task by applying principle of due professional care. Thus, audit must be carried out following the audit standards and established codes of ethics, so that results of audit report are expected to have high quality, including the audit opinions given. Failure of auditors in carrying out this matter can lead to failure of the audit process carried out. In turn, the audit results will be are of low quality.
One of the criteria set out, both by law and audit standards, is that audit opinion given must consider the problem of local government compliance with laws and regulations. Thus, auditors should plan and design an audit program to be able to detect noncompliance, whether it is caused by fraud or errors. Unqualified opinion should not be given to LGFS which contains material misstatements originating from non-compliance of local government with laws and regulations. The higher the level of local government non-compliance with laws and regulations (which is reflected by findings of noncompliance in the audit report), the lower the audit opinion on LGFS. Therefore, authors proposes an alternative research hypothesis as follows.

Ha: Auditors of the $\mathrm{AB}$ considers findings of local government's non-compliance with laws and regulations in determining audit opinion on local government financial statements.

\section{RESEARCH METHODS}

The research model used in this study is an explanatory sequential mixed methods. Explanatory sequential mixed methods are the methods used by authors to conduct quantitative research, analyze the results, and then arrange the results to explain them in more detail with qualitative research [11]. Authors want to explain results of quantitative testing with qualitative data. Quantitative analysis techniques are used to analyze the correlation between level of local government compliance with legislation and audit opinions given by the AB on LGFS. Simply put, the research methodology can be seen in the figure 1 .



Figure 1 Research Methodology

\section{Operational Definition of Variables}


There are two variables used, namely compliance level of local government with legislation and audit opinion. In detail, the definitions of the two variables are as follow.

a. Compliance Level

Level of compliance is reflected by findings of non-compliance found in the $\mathrm{AB}$ audit report. In accordance with the nature of materiality, types of non-compliance findings are divided into two groups, namely findings that indicate fraud and non-fraud. Types of fraud findings have a materiality score of tolerable misstatement accounts, while nonfraud type findings have a materiality score of $50 \%$ of planing materiality. This means that if there is misstatement on an account whose value exceeds the materiality score, the misstatement is declared subject to material misstatement [12]. In addition, auditors also considers the impact of pervasiveness. A misstatement is stated to have a pervasiveness effect if the misstatement can affect the financial statements as a whole.

In the process of determining materiality for the level of compliance variable, authors use following assumptions.
1) Materiality is only determined quantitatively and does not take into account qualitative factors because each local government has different characteristics so that qualitative factors could be vary greatly among the local governments.

2) Pervasiveness is determined by quantitative measures, which is misstatements are stated to have a pervasiveness effect if the value of misstatement exceeds planing materiality.

3) Regarding determination of the types of fraud and non-fraud findings, the types of fraud findings are determined by using criteria developed by authors based on SFAS, the Criminal Law Code of Indonesia (CLC), and Association of Certified Fraud Examiners (ACFE). This approach is carried out because the $\mathrm{AB}$ does not have certain guidelines/criteria to determine whether a problem falls into category of fraud or not. In detail, fraud criteria developed by authors can be seen in Table 1 below.

Table 1 Criteria for Determining Type of Fraud

\begin{tabular}{cll}
\hline No & \multicolumn{1}{c}{ Fraud Criteria } & Criteria Source \\
\hline 1 & Against laws/regulations & SFAS, CLC, and \\
2 & Take/defraud goods/money & ACFE \\
3 & Benefit individual/ group & \\
4 & Harm other people/local government & \\
5 & $\begin{array}{l}\text { Deliberately carried out (there is } \\
\text { an attempt to fake/hide evidence/ } \\
\text { document of transaction) }\end{array}$ \\
\hline
\end{tabular}

Based on the description above, authors provide code for materiality using ordinal scale as can be seen in Table 2

b. The AB Audit Opinion

There are four types of audit opinions. namely unqualified opinion, qualified opinion, adverse opinion, and disclaimer of opinion. Therefore, authors gives code to audit opinion on an ordinal scale starting from the highest to the lowest level which can be seen in following Table 2.

Table 2 Code of Materiality and Audit Opinion in the Ordinal Scale

\begin{tabular}{lcccc}
\hline Materiality & No Material & $\begin{array}{c}\text { Material but } \\
\text { not Pervasive }\end{array}$ & $\begin{array}{c}\text { Material and Pervasive } \\
\text { Misstatement }\end{array}$ & $\begin{array}{c}\text { Material and Pervasive } \\
\text { Limitation of Scope }\end{array}$ \\
\hline Code & 1 & 2 & 3 & 4 \\
Opinion & Unqualified & Qualified & Adverse & Disclaimer \\
\hline
\end{tabular}




\section{Population and Samples}

In the sample selection process, authors use assumption that audit quality of all $A B$ representatives are similar. By using purposive sampling, fifty four LGFS are used as with eighteen LGFS with unqualified opinion, eighteen LGFS with qualified opinion, and eighteen LGFS with adverse opinion. There is no sample of LGFS with a disclaimer opinion because there is no LGFS in the 2017 fiscal year with a disclaimer opinion. In addition, to elaborate the results of quantitative research, interviews are also carried out on ten $\mathrm{AB}$ auditors from three representative offices, namely $\mathrm{AB}$ Representatives of Jawa Tengah Province, Yogyakarta Province, and Jawa Timur Province. The qualification of the auditors are those who have experience as team leader, supervisor, and auditor in charge.

\section{Data and Data Collection}

This research uses primary and secondary data sources. The secondary data used is the $A B$ Audit Report for fiscal year 2017 and the Summary of the $\mathrm{AB}$ Financial Audit Results for the first semester of the 2018 fiscal year. Those data are collected directly from the $\mathrm{AB}$. The primary data is interviews data which gathered by interviewing auditors from three $A B$ representatives in three provinces.

\section{Data Analysis Technique}

Creswell (2014) states that in sequential mixed methods explanatory research models, researchers conduct quantitative research, analyze the results, and then compile the results to explain them in more detail with qualitative research.

\section{Quantitative Analysis}

Quantitative analysis is carried out in five steps. The first step is tabulating data of budget realization report and balance sheet in order to determine the value of planing materiality and tolerable misstatement. The second step is analyzing noncompliance findings by using an instruments in the form of table of analysis of non-compliance audit findings. The format of the table is shown in Appendix A. The criteria for determining the audit findings containing fraud are (1) against law/ regulation; (2) taking/embezzling goods/money; (3) self-benefit/group; (4) harm other people/local governments; or (5) done intentionally (there is an attempt to falsify/hide evidence of transaction).

The third step is analyzing materiality of audit findings using following criteria:

a) The basis for calculating planing materiality is total expenditure.

b) Planing materiality rates is determine by using following provisions: $1 \%$ if previous year audit opinion was disclaimer or adverse, $3 \%$ if previous year audit opinion was qualified opinion, 5\% if previous year opinion was unqualified.

c) Tolerable misstatement values are allocated using formula "(Account Value/Total Value) $\mathrm{x}$ planing materiality". In allocating tolerable misstatement values, authors assume that all accounts will be examined so that all of them have tolerable misstatement allocations;

d) Materiality analysis is carried out with following provisions:

(1) Materiality limit of tolerable misstatement value if LGFS contains fraud and 50\% of planing materiality if LGFS does not contain fraud (source: operational guidelines of audit of the LGFS);

(2) Materiality test code filled with $1=$ if misstatement is not material, $2=$ if misstatement is material but not pervasive, $3=$ if misstatement is material and pervasive (audit finding value $>$ planing materiality), or $4=$ if misstatement contains restrictions and pervasive scope (audit finding value > planing materiality)

The illustration of analysis of materiality of audit findings is available in Appendix B.

The fourth step is tabulating results of materiality test and audit findings analysis for fifty four LGs which table can be seen in Appendix C. Lastly, the fifth step is statistical testing. In testing the relationship, authors used Kendal Tau C and Somers' $\mathrm{D}$ correlation tests because the data is from the same source, namely the $\mathrm{AB}$ Audit Report, and the form of data is ordinal scale.

To strengthen the test results, authors also test mean differences among audit opinion groups of unqualified, qualified, and disclaimer using Kruskal Wallis test. This type of testing is chosen because the data has an abnormal distribution. 


\section{Qualitative Analysis}

Qualitative analysis is carried out with six steps as proposed by Creswell (2014). The first step is data processing and preparing data for analysis. At this stage, after interviews with all participants were conducted, authors conducted transcripts and tabulated data from interviews that were grouped according to the $\mathrm{AB}$ representative office, the role/ position of examiner, and the name of the examiner/ participant.

The second step is reading the entire data. At this stage, based on the data that has been grouped, researchers read the entire data and if necessary regroup them based on the interview response keywords. The third step is coding all data based on response keywords. Then, the fourth step is applying the coding process to describe the settings (domains), people (participants), categories, and themes to be analyzed. At this stage, researchers group a set of codes for later analysis. In the fifth step, researcher showing how descriptions and themes will be restated in a qualitative narrative. The coding theme is analyzed and elaborated, especially to answer this research question. Last step, the sixth, is interpreting results of analysis into deepen meaning of results of quantitative testing in accordance with the theory and literature studies that have been carried out.

\section{RESULTS AND DISCUSSION}

\section{Correlation between Compliance Level and Audit Opinion}

Table 3 below provides information on the distribution of compliance levels for each audit opinion group based-on results of materiality test and audit findings analysis from fifty four LGFSs which data can be seen in Appendix C.

Table 3 Distribution of Compliance Levels for Each Audit Opinion Group.

\begin{tabular}{|c|c|c|c|c|c|c|}
\hline \multirow{2}{*}{\multicolumn{2}{|c|}{1}} & \multicolumn{4}{|c|}{ Audit Opinion Code } & \multirow{3}{*}{$\begin{array}{c}\text { Total } \\
24\end{array}$} \\
\hline & & \multirow{2}{*}{$\begin{array}{c}2 \\
16 \\
\end{array}$} & \multirow{2}{*}{$\begin{array}{l}3 \\
8 \\
\end{array}$} & \multirow{2}{*}{$\begin{array}{l}4 \\
0 \\
\end{array}$} & \multirow[b]{2}{*}{0} & \\
\hline Compliance & 1 & & & & & \\
\hline Code & 2 & 2 & 8 & 0 & 8 & 18 \\
\hline & 3 & 0 & 0 & 0 & 0 & 0 \\
\hline & 4 & 0 & 2 & 0 & 10 & 12 \\
\hline Total & & 18 & 18 & 0 & 18 & 54 \\
\hline
\end{tabular}

Opinion code 1 (unqualified opinion) should only contain compliance level code 1 . However, compliance level code 1 does not always occur in audit opinion code 1 . There are sixteen LGFSs code 1 that have compliance level 1 and there are two LGFSs code 2 that have compliance level 2. The results of further search for these conditions indicate that the anomaly occurred in South Halmahera Regency and Kerinci Regency. In South Halmahera Regency there was a fraud problem in the Grant Expenditure account amounting to Rp1,887,000,000 (tolerable misstatement Rp408,089,927.89) and Unexpected Expenditures Rp166,266,500 (tolerable misstatement Rp34,144,696.98) so they obtain a materiality score of 2 (planing materiality Rp62,344,535,777.70). In Kerinci Regency there was a fraud problem in the Local Retribution Income account of Rp318,500,000 (tolerable misstatement Rp78,047,728.96) so they obtain a materiality score of 2 (planing materialityRp58,815,905,672.92).

Opinion code 2 (qualified opinion) should contain only compliance level code 2. However, from eighteen LGFSs, there are only eight LGFSs that have compliance level 2 . The remaining eight LGFSs have a compliance level 1 and two LGFSs have a level of compliance 4 . The eight LGFSs that have compliance code 1 may experience exceptions to the internal control system. Two LGFSs that have compliance code 4 are Batu Bara Regency and Karo Regency. In Batu Bara Regency there was a dispute over PT Inalum's Unfinished Local Tax (Road Lighting Tax) amounting to Rp205,172,961,203.9 (planing materiality Rp38,928,211,722.78) so they obtain a materiality score 4 . The value has been recorded in the Balance Sheet as of December 31, 2017, in the Local Tax Receivable account. Also, there were fraud problems (lack of volume) in the Road, Irrigation and Network Capital Expenditure account worth Rp3,191,740,431.79 (tolerable misstatement Rp1,914,951,963.08) so they obtain a materiality score of 2 . Both of these problems have been considered as exceptions in the giving audit opinion (some which lacked volume in the capital expenditure account have not been restored). In Karo Regency, there were audit findings on the Goods and Services Expenditure account worth Rp75,751,883,538 (planing materiality Rp15,208,267,591.18) so they obtain a materiality score of 4 . The findings were administrative in the 
form of realization of expenditures on activities that had not been budgeted before. In addition, there was fraud on the Equipment and Machine Capital Expenditures account worth Rp5,603,472,955 (tolerable misstatement Rp224,739,303.79), Road Capital, Irrigation and Network Capital Expenditures worth Rp3,154,267,860.21 (tolerable misstatement Rp1,096,231,467.68 ), and Cash in the Expenditure Treasurer valued at Rp189,930,300 (tolerable misstatement Rp751,623.16) so they obtain a materiality score 2. Findings on the Cash account in the Treasurer Expenditure have become one of the exceptions in opinion.

The audit opinion code 3 (adverse opinion) does not have a sample item because no LGFS has adverse opinion in 2017.

Audit Opinion code 4 (disclaimer) has eight LGFSs that have a compliance score of 2 and ten LGFSs that have a compliance score of 4 . Eight LGFSs that have a compliance code 2 are likely to experience exceptions to the internal control system.

Somers' D test results show that the correlation between level of compliance and audit opinion have a value of 0.696 with a significance level of 0,000 ( $p$-value $<0.05$ ). Based on direction of the correlation, the correlation between level of compliance as an independent variable and opinion as the dependent variable showed a value of 0.709 with a significance level of 0,000 ( $p$-value $<0.05$ ). In addition, the test results using Kendal Tau C shows that correlation between variable level of compliance and audit opinion has a value of 0.683 with a significance level of 0,000 ( $\mathrm{p}$-value $<0.005$ ). This means that there is a positive direction correlation between the level of compliance and audit opinion with a significant correlation. Hence, the alternative hypothesis cannot be rejected.

To strengthen those test results, authors also conduct a test to determine whether there is mean difference of compliance score among audit opinion groups using the Kruskal Wallis nonparametric test. This type of testing is chosen because the research data has an abnormal distribution. Based on the test results which obtain a significance value of 0.00 (p $<0.05$ ), means that there are significance differences of average compliance score among audit opinion groups.

Results of those statistical tests showed that the $\mathrm{AB}$ Auditors have considered findings of the non-compliance of local governments with the laws and regulations in the process of determining audit opinion on LGFS. The direction of the correlation is positive, meaning that the better the level of compliance of the local government, the better the audit opinion that is obtained by the local government. The results of this study are in line with the research conducted by [8] and [9] which show that the number of findings of non-compliance with laws and regulations have a significant effect on audit opinion.

However, some things deserve attention, namely the existence of LGFS with unqualified opinion but obtained compliance score 2 (material not pervasive) and LGFS which obtained qualified opinion but obtained compliance score 4 (limitation of material and pervasive scope) as can be seen in Table 3 above. These differences are generally caused by differences in the concept of fraud between authors and auditors. Authors conclude that the findings contain elements of fraud while auditors do not say so. Nevertheless, this has potential to cause problems in the future. Among the indications of the problem, there are differences in the understanding of fraud and materiality related to fraud among the $\mathrm{AB}$ auditors as described in the next section.

Then, why there is still problem of noncompliance that is not detected by auditors when carrying out audits as indicated by the existence of a number of local government heads who are caught in a problem of corruption (fraud) even though the financial statements of the local government they lead obtain unqualified opinion? For this problem, authors find explanations which are described in the following sections.

Causes of Failure in Detecting Non-Compliance

This study shows that there are several causes of failure in detecting non-compliance, among which are auditors do not pay attention on all non-compliance findings, unclear guidelines on compliance testing, various obstacles in detecting fraud, audit program which is not updated in accordance with field conditions, lack of skill and experience, limitations on amount of time and human resources, ambiguity in determining materiality, and perception of inadequate working protection. In detail, these causes are described as follows.
a. Auditors Do Not Pay Attention on All Non- compliance Findings 
Auditors agree that there is a correlation between level of compliance of local government and audit opinion on LGFS. However, more specifically, auditors state that compliance affecting audit opinion is the compliance related to the fairness of accounts of LGFS. Thus, in general, auditors only focus more on examining compliance matters related to the fairness of accounts in financial statements. So if auditors encounter two conditions of non-compliance, namely the first problem which could affect the fairness of an account and the second problem which may not affect the fairness of an account, therefore auditors will focus on the first problem. In turn, non-compliance will still exist that could be a part of fraud. The supporting statements from R5participants' statement as follows.

“......when we are going to examine the LGFS, our main focus only the fairness of the financial statement accounts. So, well, we can say it's gratitude if we can find non-compliance or weakness elements of ICS's to be included. But the most important thing is we verify the fairness of financial statements" (R.5.20)

b. Unclear Guidelines on Compliance Testing One of the objectives of the financial audit is to obtain adequate confidence so that auditors are able to provide an audit opinion that the financial statements are presented fairly in all material respects, comply with accounting standards, have adequacy disclosures, comply with laws and regulations, and have effective internal control system [13]. Thus, compliance with laws and regulations becomes a matter that must be tested by auditors. However, in the LGFS audit, the $\mathrm{AB}$ does not provide conclusions regarding the level of compliance of local government and also there is no clear provisions on the extent, type, and nature of compliance that must be tested by auditors. As a result, the nature of compliance that must be tested by auditors becomes too broad and unclear. This is revealed by participants $\mathrm{R} 1$ and R10 as follows:
"Yes. Compliance is rather difficult because the compliance that we see supposed to be compliance that directly related to the presentation of financial statements. But, there is no limitation of compliance scope. Law of State Financial Audit state all compliance in local government. Therefore, we sometimes turn aside to see everything. If we were said whether we can design our audit to detect every non-compliance, it becomes heavy if we want to see everything, that's why... then the compliance became a bias because compliance could consist of multiple things. There is no limitation, we have to see which compliance. "(R.1.4)

“.........But we have no conclusion on compliance, whether this is full compliance, half compliance, or not compliance. We don't have that. ... "(R.10.4)

c. Various Obstacles in Detecting Fraud The Technical Guidelines (Findings Code) stated that there are five subgroups of findings of non-compliance, namely findings of state/local losses, potential losses of state/ local, lack of revenue, maladministration, and indications of criminal acts. Generally, findings of state/local losses, potential state/ local losses, and indications of criminal offenses are closely related to fraud. The SFAS states that auditors must identify fraud risk factors and assess the risk of non-compliance with statutory provisions caused by fraud. If there is a risk of non-compliance indicating fraud that significantly affects the subject matter/information of the subject matter audited, auditors must modify procedure to identify the occurrence of fraud and/ or non-compliance. This fact is revealed by Respondent R7.

"Yes ... According to the SFAS, the auditor must identify the risk factors for fraud and assess the risk of non-compliance with statutory provisions caused by fraud and/or 
non-compliance. These risks must be considered as significant risks and the auditor must obtain an understanding of the controls associated with these risks." (R.7.8)

Auditors agree with the concept as revealed by participant R7, but there are several obstacles faced by auditors in the effort to detect fraud in LGFS audits. Some of these constraints are described as follows.

1. There are no standard of fraud criteria/ requirements yet at the $\mathrm{AB}$

In particular, there is no standard/ guidance on the criteria/conditions for fraud set by the $\mathrm{AB}$. Terms of fraud are only mentioned generally in the SFAS which is acts that contain intentional intentions, intentions, benefit oneself or others, fraud, concealment or embezzlement, and abuse of trust that aim to gain unauthorized profits that can be in the form of money, goods/property, services, and not paying services, which are carried out by one or more individuals from parties responsible for governance, employees, or third parties [13]. As a result, auditors use their judgment in determining whether a finding of noncompliance met the criteria for fraud or not. The criteria of fraud used by the auditors also varied, as expressed by participants R7, R8, and R10 as follows. "Our judgment and evidence on the field." (R.8.18)

"A finding of non-compliance is categorized as fraud if it meets following elements: there is an intention from the responsible parties, loss of state/region, real and certain amount, and there is an act against the law" (R.7.6)

"..so far the easiest fraud criteria are (financial) losses in the local government...." (R.8.12)

"So I think compliance will mean fraud if it meets the elements of fraud, what is that? The first is embezzlement ...... Second, he/ she broke the rules. Third, there are those who benefit, there are those who are disadvantaged, if they have fulfilled it, then it is fraud... "(R.10.10)

2. Leaders of the $\mathrm{AB}$ tends to be too conservatism in determining fraud findings

Some auditors revealed that $\mathrm{AB}$ leader tends to be too conservative in fraud findings. There is a dualism of the assertiveness of the $\mathrm{AB}$ leaders' opinion on fraud. Some leaders state that fraud must be stated expressively while other leaders are hesitant to state explicitly. In addition, there are fears of future lawsuits for fraud findings. These concerns are generally related to the strength of evidence obtained by auditors in the field. As a result, the $A B$ leaders tend to avoid audit terms that can lead to fraud in writing findings of non-compliance. For example, the $\mathrm{AB}$ leaders tend not to use term "indication of state losses/ potential state losses/state losses" in audit findings and replace them with terms "over payment". Among these were expressed by participants R1 and R2 as follows.

".......Not all leaders dare to raise findings that are a fraud. Because there are concerns about whether these findings are strong, the evidence we get is enough? " (R.2.26)

“.......... Finally, to be safe, we do not say there is a fraud, instead, we advise there is overpay. So we play with words such as overpaid, for example, to avoid loss. " (R.1.12)

3. Collusion makes fraud difficult to detect/ prove

Collusion make fraud difficult to detect, especially if collusion involves third party that is often used by auditors in confirming an issue of non-compliance. 
This is expressed by participants R10 as follows.

"Collusion is difficult. For example, we make confirmation to a hotel about the existence of stay of a guest. Then, the hotel said o yes indeed stayed like that. Even though the guest did not stay. Then who do we want to ask (laughter)? (R.10.16)

4. There are threats/dangers in fraud examining experienced by auditors Another factor that makes fraud even more difficult to detect is that threat or danger experienced by the auditors. Some auditors tend to avoid exploring fraud when there is a threat or danger. This is expressed by participants $\mathrm{R} 9$ as follows.

".......and if it turns out to be dangerous for us, yes, I will go to my friends, just stop." (R.9.26)

"Yes. Have you ever thought about it, how could our friends enrolled to AKN VIII ${ }^{1}$ (laugh), it was so scary. It is does the country guarantees us? " (R.9.28)

\section{“...we want to do a lot but when it threatens us, I think it's better to stop, yes?" (R.9.30)}

5. Lack of Willingness of Auditors to Detect Fraud

Auditors' willingness to detect fraud is also an obstacle. This is quite surprising because auditors should carry out their role professionally following audit standards. Some of the reasons that might be attributed to this factor are the security factors as described in point $d$ above and the working protection factors that are explained further in the next section. This is expressed by participants $\mathrm{R} 1$ and $\mathrm{R} 9$ as follows.

$1 \mathrm{AKN}$ VIII is a division in the $\mathrm{AB}$ which main duty is to do investigation.
"Yes, the smart one is smart. So the lack is the passion to explore further the lack. ...This is my step indeed.So high ability, lack of will, and enthusiasm. " (R.1.10)

“... It could be that this is it, noncompliance that might lead to fraud ability. It's just that if we don't want to dig deeper, so it won't affect opinion. (R.9.4)

d. Audit Program which is not updated in accordance with field condition

Majority of auditors state that the audit program has been designed to detect noncompliance and the program is quite effective. However, several factors deserve attention. The first factor is that the audit program is generic/normative. The audit program is a guideline used by the auditors in carrying out the audit in the field. The audit program should be designed at the planning stage based on the results of the preliminary audit. Unfortunately, in general, the auditors only copy the audit program from the audit preparation team or the audit program from previous years. Secondly, in general, the audit program has not been designed to detect fraud. Third, at the planning stage, the generic audit program should be modified by the audit team following the conditions of the auditee. The modification also needs to be done so that the audit program can be used to detect fraud if there is a risk of fraud. However, auditors tend not to update/modify the audit program and continue to use the generic audit program. This situation is expressed by participants $\mathrm{R} 9$ and $\mathrm{R} 8$ as follows.

"As far as I know the procedure is just like that (laugh). For example, we should make an expenditure finding, right, he is, we suspect there is document forgery. And there should be additional procedures. And so far as I know there has never been an additional procedure ..." (R.9.18)

".... But it is hoped that the audit team can modify it (audit program) according 
to the conditions on the field when it is received. Now that's just how far the modification is, although not all teams want to do that ... "(R.8.22)

e. Lack of Skill and Experience

To be able to detect non-compliance and fraud, auditors' skills and experience are necessary, including ability to identify conditions of non-compliance/fraud in the audit findings. The lack of these two competencies can reduce auditors' detection ability, specifically related to the ability to write audit findings. If the auditors do not have this ability, they can make readers of the audit report, including the opinion review team, misunderstand the real conditions experienced by the auditee. This situation is expressed by participants $\mathrm{R} 4$ and $\mathrm{R} 9$ as follows.

"Yes, yes, sure. So basically, depend on experience of the auditor, then, the ability to analyze a problem, and understanding of the entity business processes, including the rules too. So we need auditors who are capable enough. " (R.4.14)

"For me, Bro, depending on how and what the findings are, how is our way to describe what they are ..." (R.9.2)

f. Limitations on the Amount of Time and Human Resources

It is undeniable, that problem of amount of time and human resource is an important factor in the audit process, including efforts to detect non-compliance. Both of these factors can determine the depth and extent of audits in the field, including coverage, samples, and types of testing that can be done. The limitations of these two things force the audit team to be able to organize and plan audits properly, including by applying the risk basedaudit.

Regarding timing of audits at the planning stage, auditors state that the determination of time of audit, generally, is not carried out through results of an adequate analysis/ assessment. Determination of length of audit time is carried out with a budget allocation approach so that the length of the audit process does not depend on the conditions of the auditee but rather on the available budget allocations. This is revealed by participant $\mathrm{R} 1$ as follows.

"Yes. So, to be honest, the determination of the length of the audit day in the field is not based on the results of the assessment or analysis before the audit, but more to the budget. So in my opinion sometimes it's not fair.... " (R.1.20)

g. Ambiguity in Determining Materiality In terms of materiality, especially materiality in the findings of fraud, there were differences of opinion among auditors. Some auditors stated that if there are findings of fraud, any value should be considered material. Even though the value of fraud is below materiality, it is qualitatively material if management intentionally manipulates a particular purpose.

“.... I just thought about that, if there is any findings on a business trip is it fraud right? Regardless of the value, it influences opinion, right? ......... "(R.9.44)

On the other hand, other auditors state that a fraud finding is declared material if it is exceeded the tolerable misstatement value set at the time of the audit. This statement refers to the Local Government Financial Statement Audit Implementation Guidelines stating that for a problem of non-compliance if the auditors believe there are some elements of fraud, the materiality limit is set at tolerable misstatement. This is expressed by participants R8 as follows.

“.... If it is above materiality it means that there are indications that the findings will have an impact on opinion. Yes, above the tolerable misstatement. But with condition that there should be a fraud. "(R.8.2) 
Regarding this problem, participant R1 stated that the determination of the materiality of fraud findings by tolerable misstatement is to ensure uniformity and fairness in the determination of the audit opinion mainly related to the comparison of values between findings of fraud and the assets managed by the local government. In addition, the determination of tolerable misstatement materiality of fraud also allows the $\mathrm{AB}$ to be able to account for and prove more accountably if there are future lawsuits.

h. Auditors are forgiving in giving opinion

Auditors are very careful in setting audit opinions on LGFS, especially if there is a condition that can result in a decrease audit opinion on LGFS. One of these precautions is the granting of concessions to auditee to finalize findings, both by payback state losses and with other action plans. One of reasons for recovering state losses which can be considered as the process of formulating an audit opinion is when findings of compliance generally resulting in the state losses are not categorized as fraud. Furthermore, they are not even classified as (potential) state losses but rather as over-payment. This condition is expressed by participants R1, R5, and R8 as follows.

"So after the fields examination is complete, we prepare a report, they were given time to make deposits. The final deposit receipt that sent to us could be considered. ......." (R.5.26)

"It (state losses that have been recovered) still included in the Audit Report, but that it is then still considered as influential on the opinion now it will be reconsidered." (R.8.24)

"No. Because we said from the beginning, it was not a loss, not fraud, just overpayment (laugh)." (R.1.18)

i. Perception of Inadequate Work Protection As mentioned in previous section, there are potential threats and dangers experienced by the auditors when dealing with fraud problems. This caused some auditors to be reluctant to explore findings that indicated fraud. This reluctance is stronger when there is perception among auditors that working protection provided by the $\mathrm{AB}$ to the auditors is inadequate. Actually, the $\mathrm{AB}$ has tried to provide legal assistance through the Legal Subdivision in each representative office, but the practice of legal assistance provided seems to be less inadequate. This fact is expressed by participants R2 and R9 as follows.

\section{"Yes, I agree that (lack of institution protection) ..." (R.2.26)}

"There is no accompanying staff from the office. As far as I know in the previous representative office, if you really have to be an expert witness like that, there is a staff from law subdivision accompanying you." (R.9.32)

\section{Research Conclusions}

This study shows that there is correlation between level of compliance of local government with legislation and audit opinion on LGFS. The correlation has a positive direction which means that the more obedient the local government, the better the audit opinion is on the LGFS given by the AB. However, there is still a risk of audit that may occur, both in the implementation process and in the audit reporting, including in the audit opinion formulation process. Risks that might arise are:

a. Risk of failure to detect problems of noncompliance and fraud. Some of the causes are differences in concepts related to fraud criteria, failure to update audit program, potential threats/dangers experienced by the auditor, and auditors' negative perceptions on working protection.

b. Risk of errors in setting audit opinions. Some of the causes are the risk of failure to detect material non-compliance and fraud problems. Also, differences in the concept of materiality among $\mathrm{AB}$ auditors can increase risk of errors in setting opinions.

Thus, the $A B$ needs to increase the effectiveness of audit quality assurance to improve audit quality. 
This study has several limitations, namely the interview sample for qualitative research which only involved auditors from three $\mathrm{AB}$ representative offices from Java. This study do not involve auditors from outside Java who could experience different conditions. Also, authors do not conduct interviews with personnel from the Main Directorate of Planning, Evaluation, and Development of the State Financial Audit and Legal Representation Subdivision to do confirmation, especially related to internal audit guideline/regulatory issues related to fraud and work protection issues for auditors.

Based on the findings of this study, future research should be carried related to what factors can be considered in determining the time of the LGFS audit; types of threats experienced by auditors in LGFS audits, whether they are related to fraud or other problems; and how auditors perceive the work protection provided by the $\mathrm{AB}$. 
[1] Republik Indonesia, "Undang-Undang Republik Indonesia Nomor 17 Tahun 2003 tentang Keuangan Negara. Lembaran Negara Republik Indonesia Tahun 2003 Nomor 47,” Jakarta, 2003.

[2] Liputan6.com, "ICW Ungkap 10 Kepala Daerah Peraih Opini WTP Tapi Terjerat Korupsi," 2018. [Online]. Available: https://www.liputan6.com/news/read/3815707/icw-ungkap-10-kepala-daerahperaih-opini-wtp-tapi-terjerat-korupsi. [Accessed: 23-Jun-2019].

[3] Detik.com, "BPK: Opini WTP Bukan Jaminan Tak Ada Korupsi," 2017. [Online]. Available: https:// news.detik.com/berita/d-3513210/bpk-opini-wtp-bukan-jaminan-tak-ada-korupsi. [Accessed: 23Jun-2019].

[4] Republik Indonesia, "Peraturan Badan Pemeriksa Keuangan Nomor 1 Tahun 2017 tentang Standar Pemeriksaan Keuangan Negara. Lembaran Negara Republik Indonesia Tahun 2017 Nomor 1.," Jakarta, 2017.

[5] Siegel, Gary, and H. R. Marconi, Behavioral Accounting. Ohio: South-Western Publishing Co, 1989.

[6] R. A. Supriyono, Akuntansi Keperilakuan. Yogyakarta: Gadjah Mada University Press, 2015.

[7] Oseni, A. Idris, Ehimi, and C. Ojemen, "Existence and Nature of Audit Expectation Gap: Nigerian Perspective," Asian Econ. Financ. Rev., vol. 2, no. 8, pp. 1051-1063, 2012.

[8] Safitri, N. L. K. Antik, and Darsono, "Pengaruh Sistem Pengendalian Internal dan Temuan Kepatuhan Terhadap Opini Audit pada Pemerintah Daerah," Diponegoro J. Account., vol. 5, no. 1, pp. 1-12, 2015.

[9] Widodo, O. Purnawan, and Sudarno, "Pengaruh Temuan Kelemahan Sistem Pengendalian Intern dan Temuan Ketidakpatuhan Terhadap Ketentuan Peraturan Perundang-Undangan Terhadap Opini BPK atas Laporan Keuangan Pemerintah Daerah," Diponegoro J. Account., vol. 6, no. 1, pp. 1-9, 2017.

[10] S. Ningsih, "The Antecedents of Non-Unqualified Opinions of Local Governments Financial Statements: A Study on Counties and Cities in East Java Province," Asian J. Account. Res. 1, vol. 1 (2016), no. 1, pp. 16-27, 2015.

[11] J. W. Creswell, Research Design: Qualitative, Quantitative, and Mixed Methods Approaches, Fourth Edition. Thousand Oaks, California: SAGE Publications, 2014.

[12] Badan Pemeriksa Keuangan, "Panduan Pemeriksaan Laporan Keuangan Pemerintah Daerah," Jakarta, 2016.

[13] Badan Pemeriksa Keuangan, “Petunjuk Teknis Penilaian Risiko Pemeriksaan Keuangan,” Jakarta, 2017. 


\section{APPENDIX}

Appendix A: Format of Table of Non-Compliance Audit Findings Analysis






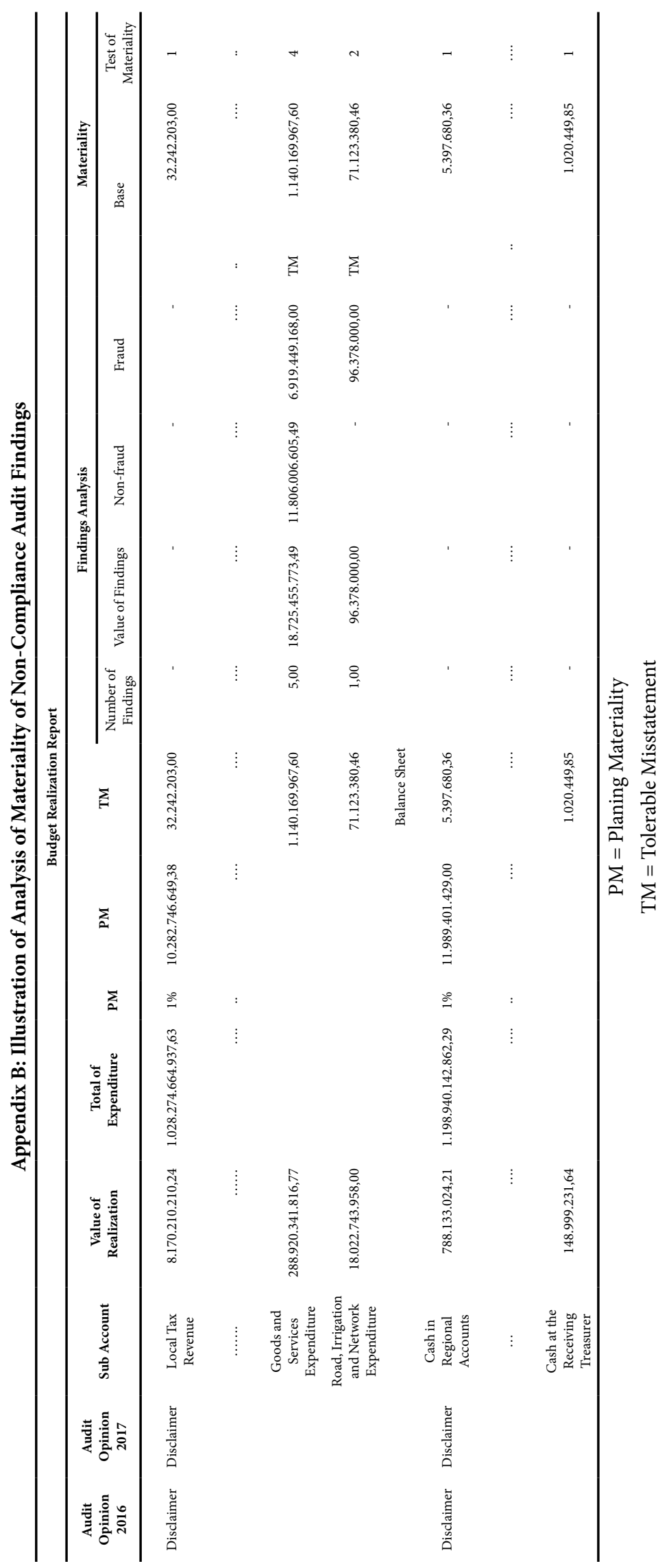




\begin{tabular}{|c|c|c|c|c|c|c|c|c|c|}
\hline $\begin{array}{c}\text { Local } \\
\text { Government }\end{array}$ & $\stackrel{0}{\stackrel{\text { ก }}{2}}$ & ิㅗㄱ & 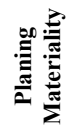 & 预葛 & $\begin{array}{l}\text { Value of Findings } \\
\text { (IDR) }\end{array}$ & $\begin{array}{l}\text { Value of Fraud } \\
\text { (IDR) }\end{array}$ & $\begin{array}{c}\text { Value of } \\
\text { Expenditure (IDR) }\end{array}$ & 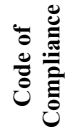 & 苂高 \\
\hline $\begin{array}{l}\text { Kab. Biak } \\
\text { Numfor }\end{array}$ & Disclaimer & Disclaimer & $1 \%$ & 10 & $19.661 .537 .681,74$ & $7.144 .077 .168,00$ & $1.028 .274 .664 .937,63$ & 4 & 4 \\
\hline $\begin{array}{l}\text { Kab. Nias } \\
\text { Selatan }\end{array}$ & Disclaimer & Disclaimer & $1 \%$ & 8 & $19.417 .565 .344,06$ & $2.162 .804 .955,76$ & $1.066 .164 .746 .908,50$ & 2 & 4 \\
\hline $\begin{array}{l}\text { Kab. } \\
\text { Simalungun }\end{array}$ & Qualified & Disclaimer & $3 \%$ & 18 & $59.012 .072 .744,29$ & $13.854 .372 .374,84$ & $2.382 .381 .117 .269,00$ & 2 & 4 \\
\hline $\begin{array}{l}\text { Kab. Boven } \\
\text { Digoel }\end{array}$ & Disclaimer & Disclaimer & $1 \%$ & 5 & $23.145 .816 .556,00$ & $1.912 .639 .406,00$ & $1.231 .853 .113 .606,00$ & 2 & 4 \\
\hline $\begin{array}{l}\text { Kab. } \\
\text { Mamberamo } \\
\text { Raya }\end{array}$ & Disclaimer & Disclaimer & $1 \%$ & 9 & $149.769 .621 .818,68$ & $15.394 .729 .176,97$ & $1.003 .953 .586 .962,00$ & 4 & 4 \\
\hline Kab. Mappi & Disclaimer & Disclaimer & $1 \%$ & 13 & $204.100 .597 .440,51$ & $160.382 .358 .746,01$ & $1.192 .831 .340 .651,00$ & 4 & 4 \\
\hline Kab. Puncak & Disclaimer & Disclaimer & $1 \%$ & 10 & $178.992 .717 .956,56$ & $7.891 .502 .992,56$ & $1.322 .725 .447 .419,00$ & 4 & 4 \\
\hline Kab. Sarmi & Disclaimer & Disclaimer & $1 \%$ & 8 & $45.838 .955 .035,38$ & $1.063 .027 .064,38$ & $1.051 .502 .778 .455,00$ & 2 & 4 \\
\hline Kab. Tolikara & Disclaimer & Disclaimer & $1 \%$ & 9 & $396.750 .426 .445,15$ & $368.094 .804 .883,02$ & $1.344 .073 .754 .657,00$ & 4 & 4 \\
\hline Kab. Waropen & Disclaimer & Disclaimer & $1 \%$ & 7 & $33.709 .589 .650,00$ & $1.946 .589 .000,00$ & $978.232 .907 .351,00$ & 4 & 4 \\
\hline $\begin{array}{l}\text { Kab. Bolaang } \\
\text { Mongondow }\end{array}$ & Disclaimer & Disclaimer & $1 \%$ & 12 & $5.596 .899 .600,49$ & $1.988 .253 .382,72$ & $1.031 .364 .819 .321,00$ & 2 & 4 \\
\hline $\begin{array}{l}\text { Kab. Buru } \\
\text { Selatan }\end{array}$ & Disclaimer & Disclaimer & $1 \%$ & 12 & $128.444 .703 .996,24$ & $4.046 .508 .886,18$ & $659.974 .284 .626,03$ & 4 & 4 \\
\hline Kab. Dogiyai & Disclaimer & Disclaimer & $1 \%$ & 17 & $99.255 .701 .061,66$ & $4.384 .124 .503,92$ & $844.038 .472 .854,00$ & 4 & 4 \\
\hline $\begin{array}{l}\text { Kab. } \\
\text { Kepulauan } \\
\text { Aru }\end{array}$ & Disclaimer & Disclaimer & $1 \%$ & 10 & $101.332 .868 .486,80$ & $21.163 .844 .805,15$ & $1.016 .898 .887 .355,86$ & 4 & 4 \\
\hline $\begin{array}{l}\text { Kab. } \\
\text { Mamberamo } \\
\text { Tengah }\end{array}$ & Disclaimer & Disclaimer & $1 \%$ & 6 & $12.053 .955 .314,98$ & $11.319 .667 .280,00$ & $1.033 .108 .697 .437,00$ & 2 & 4 \\
\hline $\begin{array}{l}\text { Kab. } \\
\text { Morowali } \\
\text { Utara }\end{array}$ & Qualified & Disclaimer & $3 \%$ & 15 & $23.617 .354 .849,26$ & $6.587 .238 .180,49$ & $937.077 .581 .668,00$ & 2 & 4 \\
\hline $\begin{array}{l}\text { Kab. Nias } \\
\text { Barat }\end{array}$ & Disclaimer & Disclaimer & $1 \%$ & 6 & $6.773 .570 .504,19$ & $3.451 .160 .866,34$ & $634.418 .292 .758,80$ & 2 & 4 \\
\hline $\begin{array}{l}\text { Kab. Seram } \\
\text { Bagian Barat }\end{array}$ & Disclaimer & Disclaimer & $1 \%$ & 10 & $30.821 .107 .212,92$ & 13.076.070.827,92 & $956.959 .343 .085,29$ & 4 & 4 \\
\hline Kota Medan & Qualified & Qualified & $3 \%$ & 10 & $34.395 .543 .033,62$ & $26.898 .193 .609,46$ & $4.395 .825 .169 .224,53$ & 2 & 2 \\
\hline $\begin{array}{l}\text { Kab. Rokan } \\
\text { Hilir }\end{array}$ & Qualified & Qualified & $3 \%$ & 9 & $11.468 .531 .940,58$ & $5.068 .468 .313,58$ & $1.552 .458 .906 .928,64$ & 1 & 2 \\
\hline $\begin{array}{l}\text { Kab. } \\
\text { Lampung } \\
\text { Timur }\end{array}$ & Qualified & Qualified & $3 \%$ & 9 & $3.196 .219 .733,22$ & $2.892 .793 .705,22$ & $1.947 .368 .023 .837,96$ & 1 & 2 \\
\hline Kota Tegal & Qualified & Qualified & $3 \%$ & 7 & 4.488.270.315,96 & $2.021 .875 .784,25$ & 1.017.223.991.907,51 & 2 & 2 \\
\hline $\begin{array}{l}\text { Kab. } \\
\text { Lumajang }\end{array}$ & Unqualified & Qualified & $5 \%$ & 4 & $2.394 .941 .183,23$ & $139.223 .199,95$ & $1.998 .722 .819 .796,24$ & 1 & 2 \\
\hline $\begin{array}{l}\text { Kab. } \\
\text { Manggarai } \\
\text { Barat }\end{array}$ & Qualified & Qualified & $3 \%$ & 5 & $1.049 .415 .743,37$ & $213.880 .210,37$ & $1.051 .883 .092 .665,14$ & 1 & 2 \\
\hline Kab. Sambas & Qualified & Qualified & $3 \%$ & 2 & $93.527 .079 .808,00$ & - & $1.638 .897 .259 .025,08$ & 1 & 2 \\
\hline Kota Tarakan & Qualified & Qualified & $3 \%$ & 4 & $3.282 .612 .861,18$ & $431.290 .651,18$ & $782.139 .143 .811,88$ & 1 & 2 \\
\hline Kota Tual & Qualified & Qualified & $3 \%$ & 9 & $19.571 .566 .784,75$ & $18.528 .818 .976,22$ & $644.680 .816 .665,73$ & 2 & 2 \\
\hline
\end{tabular}




\begin{tabular}{|c|c|c|c|c|c|c|c|c|c|}
\hline $\begin{array}{c}\text { Local } \\
\text { Government }\end{array}$ & ำ & ลิ่ & 蓠 & 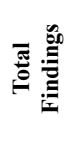 & $\begin{array}{l}\text { Value of Findings } \\
\text { (IDR) }\end{array}$ & $\begin{array}{l}\text { Value of Fraud } \\
\text { (IDR) }\end{array}$ & $\begin{array}{c}\text { Value of } \\
\text { Expenditure (IDR) }\end{array}$ & ن & ن \\
\hline $\begin{array}{l}\text { Kab. } \\
\text { Pegunungan } \\
\text { Arfak }\end{array}$ & Qualified & Qualified & $3 \%$ & 7 & $1.899 .765 .508,17$ & $1.899 .765 .508,17$ & $865.770 .027 .349,69$ & 2 & 2 \\
\hline $\begin{array}{l}\text { Kab. Penukal } \\
\text { Abab } \\
\text { Lematang Ilir }\end{array}$ & Qualified & Qualified & $5 \%$ & 19 & $18.040 .466 .729,87$ & $11.820 .112 .041,58$ & $957.737 .987 .839,30$ & 2 & 2 \\
\hline $\begin{array}{l}\text { Kota } \\
\text { Bengkulu }\end{array}$ & Qualified & Qualified & $3 \%$ & 7 & $1.000 .765 .869,40$ & $940.765 .869,40$ & $1.113 .555 .762 .686,11$ & 2 & 2 \\
\hline $\begin{array}{l}\text { Kab. Batu } \\
\text { Bara }\end{array}$ & Qualified & Qualified & $3 \%$ & 10 & $210.674 .214 .551,82$ & $4.322 .770 .049,52$ & $1.297 .607 .057 .426,00$ & 4 & 2 \\
\hline Kab. Karo & Disclaimer & Qualified & $1 \%$ & 8 & $89.655 .131 .814,21$ & $12.410 .908 .406,21$ & $1.520 .826 .759 .117,97$ & 4 & 2 \\
\hline $\begin{array}{l}\text { Kab. } \\
\text { Sampang }\end{array}$ & Qualified & Qualified & $3 \%$ & 5 & $3.221 .517 .925,56$ & $3.046 .482 .352,29$ & $1.663 .946 .531 .152,16$ & 1 & 2 \\
\hline $\begin{array}{l}\text { Kab. Pesisir } \\
\text { Barat }\end{array}$ & Qualified & Qualified & $3 \%$ & 13 & $4.482 .818 .960,80$ & $3.092 .167 .740,35$ & $811.738 .309 .194,74$ & 2 & 2 \\
\hline Kab. Bungo & Qualified & Qualified & $3 \%$ & 9 & $2.203 .350 .105,03$ & $2.014 .807 .632,77$ & $1.190 .415 .102 .747,00$ & 2 & 2 \\
\hline $\begin{array}{l}\text { Kab. Flores } \\
\text { Timur }\end{array}$ & Qualified & Qualified & $3 \%$ & 5 & $9.656 .812 .469,08$ & $507.496 .505,48$ & $1.059 .749 .190 .538,00$ & 1 & 2 \\
\hline $\begin{array}{l}\text { Kota } \\
\text { Palembang }\end{array}$ & Unqualified & Unqualified & $5 \%$ & 14 & 21.923.234.071,90 & $2.293 .758 .770,60$ & $3.141 .848 .658 .597,72$ & 1 & 1 \\
\hline Kota Bogor & Unqualified & Unqualified & $5 \%$ & 8 & $2.055 .376 .932,80$ & $1.787 .776 .406,50$ & $2.245 .590 .002 .913,62$ & 1 & 1 \\
\hline $\begin{array}{l}\text { Kota } \\
\text { Surakarta }\end{array}$ & Unqualified & Unqualified & $5 \%$ & 8 & $2.978 .429 .537,08$ & $501.202 .263,08$ & $1.768 .345 .963 .065,00$ & 1 & 1 \\
\hline Kab. Sleman & Unqualified & Unqualified & $5 \%$ & 9 & $4.935 .830 .911,89$ & $451.914 .123,02$ & 2.489.596.631.327,52 & 1 & 1 \\
\hline Kab. Badung & Unqualified & Unqualified & $5 \%$ & 3 & $1.342 .569 .683,47$ & $598.743 .678,47$ & $5.413 .936 .423 .490,13$ & 1 & 1 \\
\hline Kab. Banjar & Unqualified & Unqualified & $5 \%$ & 7 & $992.447 .235,32$ & $919.612 .298,82$ & $1.654 .535 .648 .459,26$ & 1 & 1 \\
\hline $\begin{array}{l}\text { Kota } \\
\text { Balikpapan }\end{array}$ & Unqualified & Unqualified & $5 \%$ & 4 & $5.280 .542 .000,00$ & $452.050 .000,00$ & $1.760 .740 .291 .755,85$ & 1 & 1 \\
\hline Kota Palopo & Unqualified & Unqualified & $5 \%$ & 8 & $3.786 .042 .435,98$ & $1.510 .674 .779,87$ & $963.865 .112 .821,04$ & 1 & 1 \\
\hline $\begin{array}{l}\text { Kab. } \\
\text { Halmahera } \\
\text { Selatan }\end{array}$ & Unqualified & Unqualified & $5 \%$ & 13 & $9.422 .177 .290,38$ & $6.783 .373 .004,38$ & $1.246 .890 .703 .554,08$ & 2 & 1 \\
\hline Kab. Jayapura & Unqualified & Unqualified & $5 \%$ & 6 & $3.336 .530 .521,95$ & $2.105 .249 .281,95$ & $1.229 .262 .637 .891,00$ & 1 & 1 \\
\hline $\begin{array}{l}\text { Kab. Aceh } \\
\text { Besar }\end{array}$ & Unqualified & Unqualified & $5 \%$ & 10 & $1.302 .308 .562,18$ & $197.694 .761,23$ & $1.749 .221 .368 .689,71$ & 1 & 1 \\
\hline $\begin{array}{l}\text { Kota } \\
\text { Subulussalam }\end{array}$ & Unqualified & Unqualified & $5 \%$ & 9 & $6.728 .497 .341,28$ & $299.094 .488,72$ & $754.863 .247 .888,00$ & 1 & 1 \\
\hline Kota Cilegon & Unqualified & Unqualified & $5 \%$ & 6 & $1.680 .260 .092,89$ & $1.680 .260 .092,89$ & $1.748 .539 .737 .262,00$ & 1 & 1 \\
\hline $\begin{array}{l}\text { Kab. } \\
\text { Gorontalo }\end{array}$ & Unqualified & Unqualified & $5 \%$ & 12 & $4.025 .414 .955,09$ & $1.071 .028 .135,86$ & $1.276 .223 .279 .128,80$ & 1 & 1 \\
\hline Kab. Kerinci & Unqualified & Unqualified & $5 \%$ & 12 & $1.365 .070 .798,23$ & $831.700 .720,11$ & $1.176 .318 .113 .458,50$ & 2 & 1 \\
\hline Kab. Kapuas & Unqualified & Unqualified & $5 \%$ & 3 & $452.500 .000,00$ & $107.700 .000,00$ & $1.769 .451 .163 .807,94$ & 1 & 1 \\
\hline Kab. Bangka & Unqualified & Unqualified & $5 \%$ & 6 & $2.241 .650 .300,00$ & $1.163 .229 .000,00$ & $1.085 .985 .720 .523,62$ & 1 & 1 \\
\hline $\begin{array}{l}\text { Kab. } \\
\text { Sumbawa }\end{array}$ & Unqualified & Unqualified & $5 \%$ & 4 & $3.202 .919 .293,04$ & $694.677 .475,59$ & $1.730 .576 .904 .223,74$ & 1 & 1 \\
\hline
\end{tabular}

